\title{
Small Firm Survival and Growth Strategies in a Disrupted Declining Industry
}

\author{
Gareth H. Thomas ${ }^{1}$, Evan J. Douglas ${ }^{2}$ \\ ${ }^{1}$ Australian Center for Entrepreneurship, Queensland University of Technology, ${ }^{2}$ Sasin School of Management, Chulalongkorn University \\ Keywords: strategic entrepreneurship, technological disruption, declining industries, survival strategies \\ https://doi.org/10.53703/001c.29814
}

\section{Journal of Small Business Strategy}

Vol. 31, Issue 5, 2021

\begin{abstract}
Schumpeter's theory of creative destruction argues that technological innovation facilitates the growth of innovative new firms and causes the demise of old-technology firms. But not all disrupted firms wither and die - rather, some survive and grow by utilizing strategic entrepreneurship. Whereas the strategic entrepreneurship of disrupter firms has received considerable research interest, the strategies that disrupted firms use to avoid elimination in a disrupted declining industry have been afforded relatively little attention. This paper reports on a qualitative grounded research study of firms in the disrupted printing industry and reveals three main strategies used by survivors: namely, reconfiguration of external networks; exploitation of the untapped potential of intangible assets; and the rebalancing of legacy product exploitation and new product exploration. Propositions are developed regarding entrepreneurial strategies that disrupted incumbents may utilize to survive in disrupted industries.
\end{abstract}

\section{Introduction}

It is widely accepted that entrepreneurial activity is a major driver for economic growth (Capello \& Lenzi, 2016; Huggins \& Thompson, 2015). With growth as a major target for both practitioners and policy makers the question of what drives and shapes growth is a major stream in the strategy literature (Pirolo \& Presutti, 2010; Salder et al., 2020; Tehseen et al., 2019; Yazici et al., 2016). However, the environment in which growth occurs is often overlooked. Corporate strategy and strategic entrepreneurship research has tended to focus on firms operating in resource-rich environments where demand is growing (Gans \& Stern, 2003) in dynamic and munificent high-technology markets, such as for electronics (Brown \& Mason, 2014), biotechnology (Kerr et al., 2014), and digital technology (Giones \& Brem, 2017). In munificent environments, resource availability supports the growth of firms, and provides protection against competitive and environmental threats (Baum \& Wally, 2003; Castrogiovanni, 1991). Clarysse et al. (2011) showed how the competitive environment enabled the formation of effective resource configurations in young technology-based firms. Within such firms, operational, organizational, and resource slack allows time for learning, and assimilation of new knowledge allows entrepreneurs to pursue a more explorative approach (Neill \& York, 2012). Moreover, positive external effects in such markets facilitate a degree of market forgiveness, such that product innovations can be iterated and pivoted to meet customer requirements (García-Gutiérrez \& Martínez-Borreguero, 2016; Wood et al., 2019; York \& Danes, 2014).

Conversely, firms in industries subjected to technological disruption face environments where customer demand is in decline, resource acquisition is constrained, and slack is progressively consumed. As market demand for legacy products wanes, incumbent firms experience financial distress and many are forced to exit the disrupted industry (Schumpeter, 1934; Tripsas, 1997). Whilst the effect of technological change and disruption on larger firms is well covered in extant literature (see, for example, Christensen \& Bower, 1995; Gilbert \& Bower, 2002; Gupta et al., 2016; Roy et al., 2018; Vecchiato, 2017; Wang et al., 2018), relatively few studies have focused on small and medium enterprises (SMEs) facing technological disruption that threatens their survival. Beliaeva et al. (2020) looked at how Russian firms in a range of industries responded to an economic crisis in 2015-16, and Llanos-Contreras et al. (2020) examined how family firms responded after a natural disaster. Covin \& Slevin (1989) considered the strategic management of small firms in hostile environments, but the effects of technological disruption cause the industrial environment to become increasingly hostile as time progresses. Studies of real-estate brokers in Canada (Dewald \& Bowen, 2010; Osiyevskyy \& Dewald, 2015) revealed resilience and threat response, and more recently Bodlaj \& Čater (2019) studied the innovativeness of Slovenian SMEs facing market

\footnotetext{
a Brisbane, Australia, gareth.h.thomas@mac.com

b Bangkok, Thailand, evan.douglas@sasin.edu
} 
turbulence, technological turbulence, and competitive intensity. Kickul \& Gundry, 2002; Freel, 2005; O’Regan \& Ghobadian, 2005; Rosenbusch et al., 2011; and Sahut \& Peris-Ortiz, 2014, considered innovation in the special context of small firms, for example, examining the impact of the external business environment on the firm's motivation to innovate (Liu \& Yang, 2019), or on the source of innovation (Gomezel \& Rangus, 2018; Xi et al., 2013; Zahra et al., 2009). While these studies focus on the response to change, chaos, economic crisis, and turbulence, how firms respond when their market is in long term decline due to technological disruption is less-well documented. Prior research has centered on why firms fail, rather than on how smaller firms survive by employing entrepreneurial strategies, as is our focus here.

Survival strategy for small firms is an increasingly important issue (Sequeira et al., 2018), particularly in an era of relentless technological development, causing more and more firms, particularly SMEs, financial distress as a consequence of disruption forced by new technologies and products. Although some entrepreneurs are able to learn from failure (Jeng \& Hung, 2019), the financial and psychological impacts of business failure on SME owners are severe (Shepherd, 2003; Ucbasaran et al., 2013) and the societal effects of industrial adjustment and unemployment are substantial. By studying how SMEs strategically manage the transition, from a position of financial peril to a position of ongoing profitability, this research provides novel theoretical contributions and practical recommendations that can potentially reduce the failure rate of firms and avoid the negative impact of "creative destruction" (Schumpeter, 1934) on personal and societal well-being.

This qualitative paper explores the entrepreneurial strategies chosen by firms that are surviving within the digitally disrupted print industry in Australia. Our focus on a single industry allows us to avoid disparate external influences which can confound cross-industry studies. Following consultation with industry experts, firms were selected as exemplars that have practiced successful product, process, and business model innovation over the past decade, and 14 of these firms agreed to participate in the study.

In the following sections we first conduct a literature review that explores innovation in SMEs and how this may differ in disrupted declining industries. Next, we present and discuss excerpts from transcripts of our case studies and develop research propositions. Finally, we conclude with implications for policy, practice, education, and further research.

\section{Theoretical Background}

Technological advancement can be thought of as being incremental (evolutionary), or discontinuous (revolutionary) (Koberg et al., 2003). Whilst the former allows incumbent firms the opportunity to build on existing competencies, the latter is disruptive, potentially rendering existing skills sets obsolete (Danneels, 2004; Feder, 2018; Hornsby et al., 2014; Yu \& Hang, 2010). Disrupted firms tend to be inflexible in the face of radical technological innovation, which Hill \& Rothaermel (2003) suggest can be explained by economic factors (linked to incentives); organizational factors (such as structural inertia or internal rigidities); and embedded strategies (such as links to an existing network infrastructure that restricts flexibility). The first two factors are more influential in larger enterprises, but the third factor is likely to be critical for SMEs disrupted declining industry (DDI). Strategic flexibility of firms is intensified by employing specific resource management practices (Brinckmann et al., 2019), and the configuration of both internal and external resources becomes more critical when slack is largely absent and resources are more difficult to acquire.

\section{Internal Resources}

One of the fundamentals of resource-based theory is that firms derive sustainable competitive advantage from the way in which they control both their tangible and intangible assets (Barney et al., 2011), with firm performance driven by assets that are valuable, rare and inimitable (Barney, 1991). Penrose (1960) spoke of organizational slack as an intangible asset, and wrote that "at all times there exists, within every firm, pools of unused productive services and these, together with the changing knowledge of management, create a productive opportunity which is unique for each firm". Internal slack constitutes a surplus of resources in excess of those required to simply maintain the firm (Powell \& Baker, 2011) and these can not only act as a buffer to environmental shocks (George, 2005) but can also foster greater experimentation (Nohria \& Gulati, 1996); provide strategic agility and flexibility (Jifri et al., 2016); and have a positive effect on growth (Sheppard, 2018). Slack enables investment in projects that improve performance and competitive advantage is enhanced by building strong internal capabilities that can mitigate against adverse events (De Carolis et al., 2009). Although firms with fewer resources are likely to leverage them more efficiently (Baker \& Nelson, 2005), "forcing managers to improve allocative efficiency" (George, 2005), incumbents in DDIs are forced into a fundamental re-evaluation of their utilization of employed assets.

When facing a disrupted market, some firms respond by focusing on improvements in operations and planning. Burns \& Stalker (1961) described those firms as "mechanistic" while those that adopt a more flexible approach were termed "organic". This flexibility allows incumbents to better cope with dynamic change. In new firms, innovation is the "natural state of affairs" (Miller \& Friesen, 1982), but over time established firms may gravitate towards entrenched processes which can stifle efforts to innovate, such that in more mature industries the organic can be replaced by the mechanistic. In dynamic, disrupted environments, flexibility and adaptability are paramount for survival (Miller \& Toulouse, 1986). When faced with shrinking markets the tightening of procedures reduces analysis time, and process inflexibility removes the opportunity for experimentation.

Knowledge obsolescence is a side effect of disrupted sectors where individual skill sets can become obsolete if focused on obsolete technologies. Such knowledge obsolescence reduces the firm's stock of useful knowledge and hinders the firm's absorptive capacity - i.e. its ability to absorb "new, external information, assimilate it and apply it 
to commercial ends" (Cohen \& Levinthal, 1990). In DDIs, we can expect a surfeit of knowledge tailored to meeting a diminishing demand in an existing market. Within SMEs, knowledge acquisition is critical to building a competitive advantage (Argote \& Ingram, 2000) and in a DDI the entrepreneur ${ }^{1}$ must balance the requirement to extract maximum benefit from existing knowledge with a requirement to ensure that new knowledge flows into the organization. At a more general resource level, the entrepreneur must reposition resources to explore opportunities for those resources in new markets (and perhaps outside the originallyintended use of those resources). Competency-destroying disruptions (Tushman \& Nelson, 1990) force entrepreneurs to look outside their immediate skill set to acquire new skills. Recombining resources in new ways or finding new uses for existing resources opens up new opportunities when new resource acquisition is limited. Scarcity forces entrepreneurs to consider methods such as financial bootstrapping (Winborg \& Landström, 2001); social resourcing (Keating et al., 2014); effectuation (Sarasvathy, 2001); and bricolage - the use of "whatever is at hand" and applying new combinations of existing resources (Baker \& Nelson, 2005; Lévi-Strauss, 1966; Senyard et al., 2011; Welter et al., 2018).

\section{External Resources}

A firm's ability to create and appropriate value is critically dependent on different groups of actors that produce complementary products or services (Acs et al., 2017) and this is particularly the case with SMEs which either lack the resources necessary to capture the entire value chain or find it financially prohibitive to do so. Internal resource constraints force entrepreneurs to look to their network to access new or untapped resources. Interactions with organizations in the firm's network is an enabler (Corrente et al., 2019; Davidsson et al., 2017) or facilitator of value creation (de Vasconcelos Gomes et al., 2018).

Niche expertise in a shrinking market requires entrepreneurs to respond either by acquiring new skills and expertise, or by taking their existing expertise into new markets. Disrupted firms can overcome resource constraints by making more effective use of open innovation practices, and drawing on resources and knowledge accessible from the firm's external networks (Spithoven et al., 2013). Knowledge is critical to the innovation process (Cohen \& Levinthal, 1990) and the ability to access knowledge is a key reason why firms build or enter networks with other organizations (Huggins \& Thompson, 2015). Morris et al. (2015) argue that high-growth ventures rely on a network of lesser-growth ventures to fuel growth. Social networks provide knowledge corridors for entrepreneurs (Sarasvathy, 2001) and diversified networks offer entrepreneurial firms a major advantage (Ritala et al., 2015) as they provide access to a rich knowledge base.
But in DDIs the entire industry is under threat, such that the firm's immediate network is also suffering from excess supply of obsolete resources. If the external network of the firm is largely drawn from the same industry, then networked organizations all face the same threats. Diversification into networks outside the confines of the disrupted industry will serve to facilitate the discovery of new opportunities. Accordingly, identifying new opportunities to enable survival in a DDI requires vision beyond the firm's immediate network.

\section{Methodology}

The first step in our investigation is to understand the population from which our sample should be drawn (Eisenhardt, 1989), which in this case is the population of SMEs in the Australian print sector. The second step is to consider representativeness - not necessarily whether the chosen sample is representative of the population as a whole, but whether it exhibits the necessarily characteristic under investigation. Following Seawright \& Gerring (2008), sample firms were selected on the basis that they were a-typical, extreme, deviant, influential, or most different. The research team consulted with knowledgeable experts in the sector (drawn from equipment manufacturers, respected business owners and journalists) and a selection was made based on their apparent success in the face of disruption. The research focused on observational techniques drawing heavily on Yin's (2003) approach. Data was collected in a series of interviews, each lasting between one and two hours. The structure was open-ended with questions aiming to reveal the major strategic decisions made by the senior management team. The interviewer explored the influencing factors affecting decisions, and depth of storytelling was prioritized over disparate data collection. Structure was provided by an overall guidance protocol. A grounded-theory approach was taken with an aim to produce knowledge by collecting facts that provide the basis for induced theories. The research emphasizes how and why entrepreneurial strategies are made in context (Welter et al., 2018) using an interpretivist approach.

Each interview was transcribed by the authors, offering the opportunity to learn and reflect after each event. Analyzing the language used after each company visit also offered the chance to revise some questions for subsequent meetings. Following each interview, in-depth reviews took place within the co-author team, enhancing the opportunity for reflection and to view issues from an alternative perspective. Logging the actions taken by firms enabled the research team to triangulate commonalities and observe similarities in approach.

A manual coding approach was adopted, beginning with open coding and gradually moving towards selective coding. Following Flick's (2006) pattern of analysis, the coding began with more abstract concepts (e.g. "what are the un-

\footnotetext{
1 For convenience of exposition we refer to the owner-operator of the SME as "the entrepreneur" to distinguish between firm actions and the owner-manager's decisions. Small firms often exhibit the "upper echelon” effect (Hambrick \& Mason, 1984), where the firm effectively acts in the way that the senior management (or the owner-operator) determines it should act.
} 


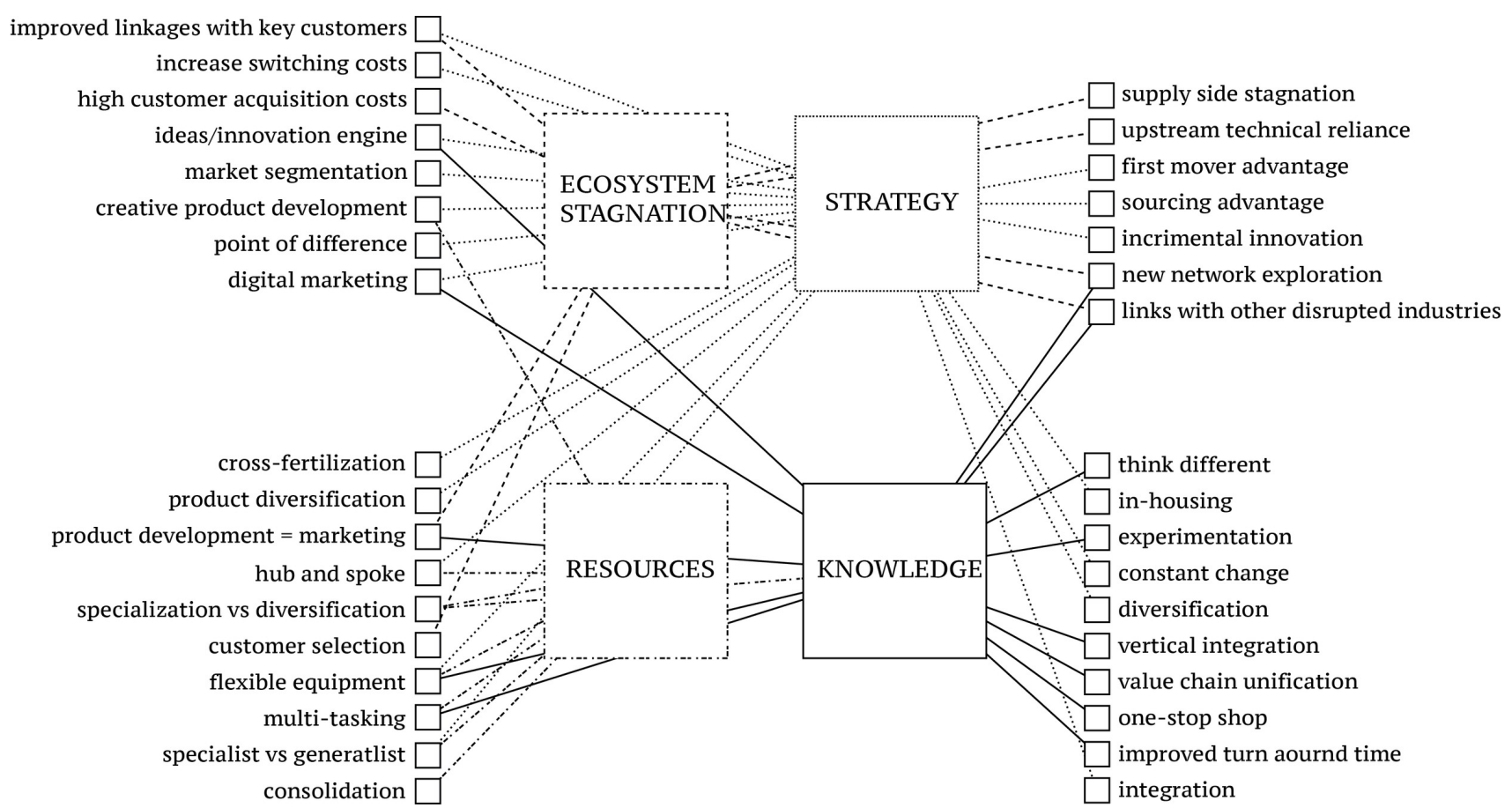

Figure 1. Linkages between open-coding and four major concepts

derlying decision-making processes at play?"), then evolving into more concrete concepts (e.g. "what strategies are being employed by the entrepreneur in this situation?"). Open-coding - based on keyword analysis - identified four abstract concepts predominant in interviewees' comments (see Figure 1). Multiple connections were identified from keywords to each of the four abstract concepts.

Linkages were built as relationships between concepts emerged, and patterns and themes began to solidify following the sixth interview. By the twelfth and fourteenth interviews, clear similarities emerged, showing a convergence around three overarching strategies. With these four abstract concepts in mind, further analysis of the keywords showed that interviewees' strategic responses to disruption coalesce around five major themes. These themes were subsequently developed into research proposals that may be tested in subsequent research to build new corporate entrepreneurship theory ${ }^{2}$.

\section{Findings}

The printing industry has undergone major disruption over the past several decades. The digitalization of the supply chain with the advent of desk-top publishing fundamentally altered the way these firms interact with their customers. Process flows were re-invented and core skills re-evaluated. Demand for print-on-paper fell as the distribution of information shifted to digital formats. But despite declining industry production volumes and the falling number of print firms (Australian Bureau of Statistics, 2016), some firms continue to flourish and the uses of print are multiplying as print is applied to an ever-increasing diversity of substrates ${ }^{3}$. Within such a disrupted market, entrepreneurs are constantly forced to look for new opportunities to innovate ${ }^{4}$.

"Back in 1992, under 1\% of your work came in digitally. By the year 2000 , it would have been $75 \%$ came in digitally. That has now progressed to more or less $100 \%$, 99.9\% in 2018." [I]

"In the early 2000s - you know - if we sent out 250,000 pieces in the mail, the phones would ring off the hook. If we sent them out today, we wouldn't get a phone call - that's how much it has changed. So it's quite staggering when you think of it." (L)

“Just offering a copy or offering a print service doesn't look at what the clients need to [do] and what their problems are ... What are you going to be doing? You just going to be selling on price. So you have to look for what the new technology allows you to do." [I]

2 This sample size compares favorably with similar qualitative studies conducted by Eisenhardt (1989), Grégoire et al. (2010), Ashworth (2012), and Kirtley \& O’Mahony (2018).

3 Recent developments in printing technology has seen innovations such as raised surface printing (for example, for use by the partially sighted) as well as textured printing (for example, in the production of more authentic reprints of works of art). Other growth areas include packaging, and printing on different substrates including wood, metal, \& film (for "wrapping" items, buildings, and vehicles).

4 In the following quotes, the identity of the respondent involved is indicated by the letter in brackets following the quote. 
Traditionally, many SMEs operating in the sector have relied on technical advances made by their suppliers to drive their innovation. However, supply-side product development has stagnated in recent years. As a result, entrepreneurs have not only suffered demand-side disruption (with the shift to digital media) but also supply-side atrophy, with a reduction in the frequency of innovative solutions from suppliers.

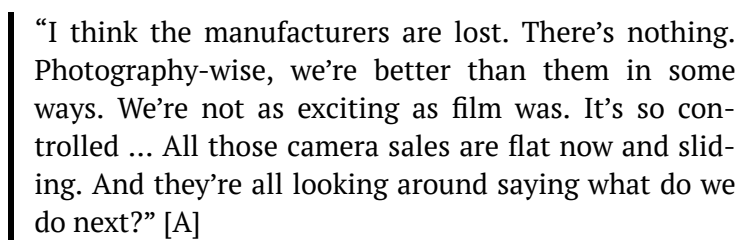

SMEs relying on technical innovation created upstream have built an unhealthy dependency on upstream technical innovation, particularly in print machinery and supplies. Downstream printers concentrated more on how to best utilize new production equipment rather than on developing internal skills and capabilities in innovation, or systems to foster innovation built on factors other than the procurement of new plant and equipment.

"They are not doing anything to save themselves be-
cause they are used to be being fed by Fuji and Kodak."
[A]

An offshoot of this practice of chasing the latest (supplier-provided) printing machine has been a tendency to look for new supply inputs, beyond just the latest version of printing machines. Whilst most rely on supplier innovation, others adopted a more independent approach and have made intentional strategic decisions to engage in internal innovation.

"The trick in our industry is to become aware of this product and to offer this to clients and charge a premium before everyone else just makes it mainstream.... it's utilizing the technology that's out there to keep yourself up with what people might be doing." [M]

As markets fragment, this has actually opened opportunities for diversification and specialization. Firms, such as those managed by $\mathrm{M}$, operate at the front end of product innovation - searching for new substrates, new inks, and new printing methods. Their expertise in finding new applications has become their point of difference, and the actual printing may be outsourced to other printers hungry for work.

\section{Ambidexterity}

In a DDI, the pool of similar customers to supplement the falling demand of existing customers is a shrinking one. Resource constraints and risk aversion can discourage entrepreneurs from pursuing all but the safest opportunities. Retreating to one's core competence and searching for a competitive advantage in quality, or ever-shorter lead times, are options pursued. In such an environment, our research reveals SMEs extracting maximum value from existing relationships and sees them invest in process improvements that increase production flexibility and reduce lead times. But such incremental innovations can only have a limited effect within the context of a DDI. Exploring within pre-existing markets and within pre-existing networks can result in failure to discover more rewarding alternatives. Successful entrepreneurs in our sample have invested more widely in this explorative process to enhance their ability to discover new opportunities.

Deprived of the benefits of operating within more munificent markets, successful entrepreneurs have also restructured their external environment to access resources unavailable within the boundary of their own firm. In focusing on extracting maximum value from key customers, expanding up or down the value chain has expanded the reach of the firm into new networks. The creation of these new networks has proved critical for survival and expansion. If a firm's network is not refreshed and previous clients operate on a trajectory of gradual decline, the firm will also decline. Hence, building on their opportunity-recognition skills, successful entrepreneurs reconfigure their networks as a way of absorbing innovative ideas not only from their suppliers, but also from their customers, such that an external influence becomes a source of inspiration.

Some of the entrepreneurs sampled in this research moved to work more closely with firms in the retail sector, which has also been disrupted by digital innovation (online commerce) and is seeking new print-based products to attract customers back to their bricks-and-mortar stores. Meeting this demand has necessitated both process innovation (e.g. increased production flexibility), and product innovation targeting the point-of-sale (POS) market. Leveraging the flexibility offered by recent production machinery acquisition, firms' print offerings are changing from printing ink on paper to fabrication with ink (using more rigid substrates that can be erected as displays, creating textured products from ink, etc.).

Augier \& Teece (2009) argue that competitive advantage is built on a mastery of a three-stage process of continuous innovation, namely identification, exploitation, and threat management. In line with their first stage of continuous innovation, successful entrepreneurs develop a capability to sense new opportunities.
“The way that we've evolved is that we've had to change, not to just the market shifts but also the mind- set of staff. You can't keep just hitting the same. Our staff don't do the same job every day that they used to do. They are having to do multi-tasking ... The type of work that we are getting in, you just can't say, 'This is all I do, just this'. Those days are gone.” [G]

The second stage is their capacity to exploit opportunities - mere investment in new machinery is insufficient. The firm must master the capabilities of the machine, turn ideas into prototypes and bring these to the attention of customers. And finally, the firm must develop a capacity to manage threats - in other words, by managing the resources it has available within its network as well as within the confines of the firm.

\footnotetext{
"Every 18 months we have a change with the type of work we are doing ... the customers stay the same but the type of work really changes." [E]
} 
The need for continuous innovation to create a sustainable competitive advantage forces entrepreneurs to find a balance between exploiting existing opportunities and exploring new opportunities, i.e. ambidexterity (Lubatkin et al., 2006). When market demand falls, risk avoidance can induce entrepreneurs to allocate promotional and other resources to existing customers. An over-concentration on trying to exploit potential revenue streams from largely undifferentiated legacy products can result in severe price competition. As demand diminishes, industry peers tend to offer discounts to "buy" business to utilize excess capacity on existing machines with high monthly repayment costs. Investment in process innovation is a way to overcome this and maintain close linkages to customers' ordering and inventory control systems.

Accordingly, finding the balance between investment in new product development for new customers and investment in process efficiencies to extract maximum value from existing customers is a critical balancing challenge for entrepreneurs. Entrepreneur E has invested in process innovation such that his company becomes a virtual division within his customer's business - enabling visibility throughout the supply chain for customers, right inside his business.

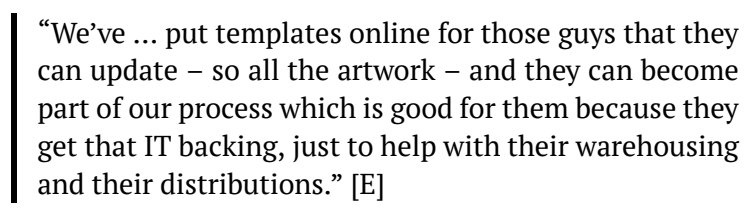

Previously, the informal nature of procurement systems in the market meant that entrepreneurs would find that a change in a client firm's purchasing manager resulted in the new manager's preferred print supplier winning subsequent contracts. Increased interlinkages with customers' order processes enable a degree of insurance from changes in procurement personnel. These barriers to the erosion of a competitive edge are built by increasing clients' switching costs (Burnham et al., 2003; Klemperer, 1987).

\footnotetext{
“They're so tied in with our processes now you probably call them a captured client. I mean, we really look after them but they've become part of our process. And there's a couple of customers like that here they all kind of rely on us to fulfill that need for them. We do it quickly and make it easy for them.” [E]
}

In such new niches, production quantities are small with unit profitability higher, so building barriers to entry presents increased difficulties. Capturing customers in the market for these products is more challenging than with legacy products, and repeat business is less predictable and sales revenue more unstable. Customers expect suppliers to provide a consistent and constant stream of product innovation. For E, building this product innovation ability has been a purposeful strategy. Entrepreneur E aims to create an innovative engine in the firm to develop concepts and ideas.

"I come to them with a concept and explain it. And what I explain... they'll come back with something far better." [E]
Under this segmentation, E is strategically tailoring innovative solutions - product or process, or in some cases both - to specific customers or specific market segments. New customer acquisition costs are typically high for SMEs, and more so in a DDI, so extracting maximum value from existing customers is a priority.

"If you can do a hundred percent of a customer's print
run, it means less money that you've got to spend on
generating new customers. So you might do 5\% of their
work, to get another $20 \%$ of their work. The cost factor
is very minimal compared to where you need to gener-
ate new customers." [K]

Whether the point of difference is in innovative product designs [e.g. M] or in process integration [e.g. E], finding the balance within a resource constrained environment is critical. The foregoing discussion suggests Proposition 1:

Proposition 1. A strategic mix between mass-produced legacy products, at relatively low margins, and short-production-run new products, sold with higher margins, offers firms a route to mitigate the negative effects of market disruption.

\section{Cross-pollination}

Process innovation strategies are well suited to formal supply chain operational systems, but less well suited to informal systems. At the level of the SME, business-to-business operations may not necessarily be based on formal procedural approaches and instead may be more ad hoc in nature. Outsourcing can be used to fulfill customer demand, particularly if based on products outside the core competence of the firm. The case results reveal that in such a situation, firms draw on external network resources as a way of overcoming internal skill deficiencies. Customers may choose a supplier based on their ability to deliver creative products, which in turn can result in the proceduralization of order systems which delivers further opportunities at a later stage. As a result, innovative product development can create opportunities for subsequent process-driven innovations:

"You ring up a customer and say I'm just selling print and they're just not interested. It's not innovative. It's not different. No wow factor about it. But if you can show them some photos of some 'out there' point of sale that we've been doing, they go all, 'I love that'. And you go in and talk about that. But you can lead into more the mass-produced stuff." [F]

This strategy required the identification of a creative point of difference.

"We used to have a machine .... which was the only dig-
ital printing machine at the time which could do metal-
lic colors ... and the agencies loved it. The number of
customers that I got off the back of that was just un-
believable. You've just got to have one point of differ-
ence." [F]

Furthermore, where some firms have concurrent income streams, these can work in parallel to generate business for partner streams. Entrepreneur L has expanded his business beyond its initial print-focused core to add wider software 
capabilities. This has enabled him to offer digital marketing as well as more traditional direct marketing services. But it is the interlinkage between the two that drives sales.

"We can communicate to a database through multiple different channels. So when we go in to pitch to that, we say, oh and by the way, we also have print solutions. So then we'll talk about print.” [L]

Entrepreneur K's firm operates two divisions, each generating opportunities for the other.
"Once we started the packaging side that was a stand- alone business. Both of them have separate profit cen- ters. So they have to generate their own income out of it and you've got to work with both of them. Simul- taneously. There are a lot of opportunities that come from the packaging side to the print side. So we deal with [firm name redacted] and they may use promo- tional stuff, magazines brochures, that sort of stuff. So that's where the print side picks it up." [K]

Entrepreneur $\mathrm{K}$ has seen the benefits of this cross-pollination and is now expanding his company's capabilities into a third product sector.

\begin{abstract}
"So having the wide format [printer] now give us the ability to do signage. That sort of stuff. But it also gives us the ability to tap into markets that we would not have been able to tap into before which will then pick up the work for the offset side as well.” [K]
\end{abstract}

For some entrepreneurs, these new product offerings are little more than a marketing tool. Entrepreneur I described how offering 3D printing to potential customers was a way to position his company as working at the leading edge of the sector, aware that timing of that leap into a new technology is critical.
"But at the moment [3D printing] also a very good point of difference for us. At the moment it's a marketing tool. There's a fine balance between ... the leading edge and the bleeding edge. The bleeding edge is when you're not getting a return on the money that you in- vested because the clients - even though the technol- ogy is good - the clients aren't with you.” [I]

Where new resource acquisition is a high-risk strategy, investment in highly flexible resources is a strategy that can help mitigate against this risk. This suggests Proposition 2:

Proposition 2. Agile organizations facilitate the crosspollination of ideas, skills and opportunities. Innovative product development can create opportunities for subsequent process-driven innovations.

\section{Rebalance between Tangible and Intangible Resources}

Historically, the printing industry has had a highly skilled and specialized workforce. Apprenticeships for typesetters, sign writers, and lithographers were long and arduous. Digitization rendered many of these skills obsolete and the focus of the printing process shifted from manual dexterity to creativity and process control as the role of the operator progressively diminished. But in more recent times, the fragmentation of consumer demand is necessitating a shift in emphasis again, from accurate reproducibility to product creativity. Newer machines are now more like artisan's tools, and a further locus of product innovation can be added to digital input - i.e. the way the machine is used. Unleashing the creative skills in employees is a means by which SMEs can maximize the utilization of key intangible assets - i.e. the creativity of their own workforce. This is causing a shift in the source of competitive advantage, from monopoly power and the ownership of tangible assets (for example, multi-million dollar offset printing presses) to inimitable intangible assets like the skills and knowledge to provide a stream of innovative new products (Kyläheiko et al., 2011). To meet market demand for shorter print runs, investment has shifted from offset printers to more flexible production equipment, and consequentially process innovation has enhanced the service offering through reduced lead times. Focusing on these intangible assets, successful entrepreneurs in this sample have developed conscious and intentional strategies to foster flexibility in product and process innovations.

Typically, SMEs work within resource-constrained environments (Baker \& Nelson, 2005), but within DDIs this is often compounded by the difficulties of acquiring new resources. Accessing resources can be done in a formal sense, through the creation of joint ventures; or informally, through the process of subcontracting or even ad hoc by more opportunistic means, when required. Entrepreneur E described a number of joint ventures geared towards the production of specific printed products using specific technologies - for example, offset, or label printing. This approach was particularly useful when investment in production equipment was extremely expensive - it was a way of spreading risk and pooling market access. Entrepreneur L's strategy was the pooling of demand to extract maximum value from highly expensive resources.

\footnotetext{
"We thought about ganging up print, instead of running a sheet with one business card on it we'd run a sheet with 20 business cards on it, which meant we could drive the price down. A hub and spoke system and the spokes [are] the franchise system." [L]
}

This hub and spoke solution is a way in which a dispersed demand (both by sector and geography) can be met by a central printing operation. In effect, the hub outsources sales and marketing to in-field specialists and conversely, field-based companies can rely on a high print quality from a central hub. Such a relationship can be built on more formal franchise-type relationships (as in the case with entrepreneur $\mathrm{L}$ ) or on a common agreement with similar (typically geographically dispersed) companies.

$$
\begin{aligned}
& \text { “... innovation should be about more than just buying a } \\
& \text { new machine. ... We began it because we thought buy- } \\
& \text { ing an Indigo or equivalent for any one of us was certain } \\
& \text { death. However, sharing the market, having four sepa- } \\
& \text { rate sets of customers would mean that we could pay } \\
& \text { for it." [A] }
\end{aligned}
$$

In this scenario the entrepreneur sits as a central processing unit for knowledge gathered from his or her immediate network, and it is the entrepreneur's ability to recognize the opportunity and harness the creativity and harness 
the resources in his/her immediate network that yields a competitive advantage.

\begin{abstract}
"We've tended to attract more the innovative sort of customers too ... They create it themselves, but they need our experience and knowledge and materials and equipment. And because we do ... testing for ourselves as well, we tend to invent stuff that's a bit unusual." [E]
\end{abstract}

However, firms in DDIs face a specific challenge in this area as investors hold prejudicial views on future returns on investment. The decline in market size and increasing fragmentation of demand means access to funds becomes increasingly challenging. Entrepreneur $\mathrm{G}$ explains how his bank rejected his application for finance by referring to a study detailing the demise of firms in the print industry.

"It's really hard. Even financing it. You go to the bank
and they bring you a white paper on the print industry
which is this thick." [G]

One way to counteract this is the choice to invest in more flexible equipment or the reconfiguration of existing equipment. Entrepreneur A reconfigured existing resources and combined them in a different way to produce new products.

\begin{abstract}
"It's modifying existing equipment to accept this [particular] paper and then building a system that would allow it to be printed on. .... It takes up a machine for half a day per week. We modified the machine but also the process of not following traditional paper manufacturers and traditional quality expectations and building something that's very, very different.” [A]
\end{abstract}

The resources battle is shifting from "hard" resources like printers - to "soft" resources based on flexible machinery and soft human skills like new product creation. This innovation web draws on the power of suppliers who develop flexible product machinery, the dynamics of disrupted market demand and the collective linkages with other firms in the sector and beyond. The foregoing discussion suggests Proposition 3:

Proposition 3. In a disrupted industry, firms that rely on external resources for product innovation will fare worse that firms than invest in internal intangible human resources.

\section{Knowledge Management and Absorptive Capacity}

Barney (1991) highlights that the acquisition of strategic resources depends on the unique historical position of the firm - the make-up of internal expertise dictates its ability to exploit market opportunities. It is not only continuous learning processes that allow entrepreneurs to develop and grow (Secundo et al., 2017), but also the quality of the employees in the firm itself. Through careful staff recruitment and training, and by encouraging multiple skill acquisition, a flexible skill base and an aversion to the hiring of specialists (whose skill set may soon become obsolete) is one way in which entrepreneur E counteracts the dangers of structural rigidities. It is the ability to consistently and incrementally acquire new skills that enables the firm to maintain a cycle of constant innovation. If disruption necessitates an ability to learn and acquire new skills, then dynamism and flexibility within the organization has contributed towards longevity. Barney (1991) noted that "any strategy that exploits [production] machines themselves is likely to be imitable”. Perhaps this observation is a product of its time where production machinery was more inflexible and confined to a limited number of tasks - typical amongst firms where production lifespans and production runs are long.

"People [employees] coming here don't have to do an apprenticeship, and in two weeks we can teach them to use an Indigo. In two weeks, we can teach them to use a flatbed printer or the Konsberg. And then they're off and racing and they want to do more." [O]

Increasingly, machinery is becoming ever more flexible and the ability to exploit the full potential of machinery very much represents a competitive advantage for the firm.
"We have what's called multi-tasking for all our staff. So when we employ them, we employ them for more than just one position. We employ them for three posi- tions. So there will be an overlap with another couple of positions. So a small offset operator, he learns to run the labelling machine as well. So if the labelling opera- tor is away, he jumps over onto that. He multi-facets on the Ryobi, the large press. The big press operator is also a binder. So there's going to be three sets of operations on each operator, or each person in the organization so that when someone's off we can move people around. Or alternatively, if we get busy, we run two 8 hour shifts or two 12 hour shifts depending on the need." [K]

Successful entrepreneurs understand that building the absorptive capacity of the firm is a critical way in which to build a sustainable competitive advantage.
"I went to great pains to show them that through all of this, it would remove some of the types of work that they do and give them the opportunity to learn new skills they could leverage into something else ... I fig- ured that if I hired from within the industry, I would be getting the same as everybody else has. And I really didn't want that. I wanted people thinking differently and I wanted people to bring a different perspective to this business. We all have enough background here. I just needed the different perspective on everything. Di- versity. [O]

Entrepreneur E actively encourages the flexibility of employees as well as the flexible use of machinery as a way of fostering a continuous learning process. This not only aids knowledge acquisition and enhances dynamic capabilities within the organization (through the cross-fertilization of skills), but also knowledge transfer and absorptive capacity (employees become better at learning).
"I've got a large format estimator who works for me who keeps outsourcing stuff. Drives me nuts. I keep saying let's just have a go at doing it here. Don't send out to the cabinetmaker. Let's just see how we go. And are we getting better and better doing that stuff.” [E]

Entrepreneur E's reference to cabinetmakers refers to recent technological advances in flat-bed printers which allow for increased fabrication opportunities based on inter- 
changeable heads: the head of the printer can be interchanged with a device to cut rigid substrate materials, such as wood and plastics, into shapes that can be assembled as free-standing point-of-sale promotional signage.

Successful entrepreneurs realize that empowering staff to experiment builds knowledge acquisition and recognize that "the ability of a firm to recognize the value of new, external information, assimilate it, and apply it to commercial ends is critical to its innovative capabilities" (Cohen \& Levinthal, 1990).

\section{"There's so much hand work here. I encourage all the ... [employees] here to have a play on the weekend. If they've got a home project they want to do, come in and do it. They'll learn new processes." [E]}

\begin{abstract}
"And he came in and he looked around and he built some walls, and he built a desk out of this media [substrate material]. He just put it all together and then he created all this furniture in there that he made himself.” [O]
\end{abstract}

This is not to underestimate the challenge of finding the right balance between flexibility (ability to learn new skills) and expertise (ability to develop sufficient in-depth skills). Learning to learn is thus a critical skill for all businesses, but even more so where firms are using flexible production machinery in a dynamic market when targeting the long tail for sales revenue (Anderson, 2009). In a study of the US chemical and electronics industries in the 1960s, Cooper (1964) observed that "one really good generalist may be more effective than teams of average specialists". Entrepreneur E emphasized his desire to recruit astute generalists and an aversion to specialists.

\begin{abstract}
"When someone is a specialist in this business it's pretty dangerous because when you are a specialist you cannot last forever. And we've had a lot of specialists go from here over the years - just through natural attrition but also we've retrenched people that basically what they do doesn't exist anymore." [E]
\end{abstract}

Inflexible, embedded, traditional skills and knowledge can themselves become a disadvantage if management over-generalizes from previous experience (Eisenhardt \& Martin, 2000). Balancing the experiential with the analytical in such an environment is key to coherent and effective strategy creation. Furthermore, there is a blurring of the boundaries across business sectors as company's knowledge-acquisition skills accelerate.

\footnotetext{
"You can never stop trying to do something else in this business because you will just be swallowed up ... In a few years the only companies that sell promotional stuff... will be print companies.” [O]
}

This suggests Proposition 4.

Proposition 4. In a disrupted industry, selecting innovative customers is critical in the process of knowledge and skill acquisition.

\section{Vertical Integration}

At a very basic level, the print production process follows four distinct steps. First, text and images are created. Im- ages are then manipulated (through a process of color management) in order to convert images to a format appropriate for the printing process. Thirdly, ink is applied to a substrate, and finally the printed output is fabricated in a way that meets with customer requirements. Historically, these four processes were fragmented, with expertise required throughout the value chain but as technology has advanced, these specialized skills have gradually become obsolete and what was a highly differentiated supply chain has gradually become more functionally concentrated. This, coupled with fragmentation of market demand, has created opportunities for entrepreneurs to reconfigure their value chain to best service their chosen market segments.

Entrepreneur D was forced into vertical integration because of a disruption to his supply chain. Initially his firm focused on initial front-end (color management) software, but subsequently, in-house printing became its major point of difference. Others have moved in the opposite direction - from merely a traditional, core expertise in print - adding upstream skills in software development and data management. Entrepreneur L analyzed where print was used and has now re-framed this usage in a digital framework (for example, tender documents). As a result, their offering to customers has grown into a digital-print hybrid solution.

"I think the biggest challenge the print industry has without doubt is the ability for those individuals to change their mindset from a predominantly print business to a diversified offering, particularly in the digital arena.” [L]

"What we have done has changed our whole model so that it's not primarily focused on print. But it's more on a collective of digital integrated marketing solutions which we've built the software for full online product management.” [L]

Within the business-to-consumer (B2C) market, entrepreneur $\mathrm{A}$ has also ventured downstream in search of more value-added services.

"I feel they are leaving money on the table because I
know the market wants new products. They might not
want the old products, or the number of old products.
But they want something. So, we built this retail space
and did a significant increase in our pricing to handle
this and to sell them these beautiful wooden products
and albums and stuff." [A]

The unification of the value chain under one roof is also redefining the way knowledge is managed within the company. Process mastery is a given, and the operator now acts as advisor to the downstream customers. This has made for shortening of the supply chain with more functions inhouse and the ability of one operator to control an entire workflow that may have previously required the input of half a dozen skilled operators.

"We did the whole creative design, put the strategy together, did the editorial, wrote it from bullet points from the brief, we printed a document, we printed a case-box that opened up - we put laser covers made out of timber that was etched into the timber [and] there was USB's with etching into them. It was a whole presentation piece. And we turn that around in 7 work- 
ing days. From nothing and it was all done through the Easter break. And they were blown away. And that was using all the pieces that we have in the building and that relates back to our suppliers. Because if we didn't have the laser, we wouldn't be able to do that.” [G]

Responses received from interviewees suggest that the length of the supply chain in the industry is shortening. Previously segmented by the need for complex skill acquisition at each step of the production process, technological advancement means that complexities in the production process have been simplified. Vertical integration also allows for a greater control over costs, closer monitoring of quality, and is a way to shorten lead times. Mastery of the entire process is a way of creating a competitive advantage.

"Three years ago we put in the wide format and stitching-trimming line. So we started to vertically integrate the business. So anything that we were outsourcing we looked at the machinery that we could do internally ... We were going to become too expensive and weren't able to maintain a competitive edge. So to get that competitive edge and in the market you need to look at how to integrate your organization, so you can control your costs a lot better." [K]

"Quality is number one. You can innovate with that sort of stuff in a lot of cases. It's pretty much standard machinery, so you are limited to what the machinery can do. But the biggest thing that I look at is quality and turn around.” $[\mathrm{K}]$

This research revealed that successful entrepreneurs aim to become experts in their customers' needs, rather than experts in a particular skill set.

"What we are trying to do as a business - and I guess
most of these businesses are trying to do - is to consol-
idate all of their clients and give them more of an offer-
ing." [O]

These findings suggest Proposition 5.

Proposition 5. In a disrupted industry, skill acquisition in related vertical markets is key to enhancing customer service and speeding time to market and this process is more beneficial to sales growth than outsourcing production to external networks.

\section{Discussion}

As shown in Figure 2, we were able to triangulate the strategies employed by firms and our findings show a convergence towards three major strategies - namely, the reconfiguration of existing ecosystems or the creation of new ecosystems; a concerted effort to exploit previously untapped, dormant intangible resources; and a rebalancing of the exploration vs exploitation dichotomy. However, these strategies are not independent of each other. Our research proposals identify actions taken by successful entrepreneurs in the face of disruption. Some of these actions are based on multiple strategy adoptions. Entrepreneurs' actions may address multiple strategies simultaneously which may or may not reinforce or weaken other actions. We should therefore view these strategies as sets of actions, some of which may interact with others.

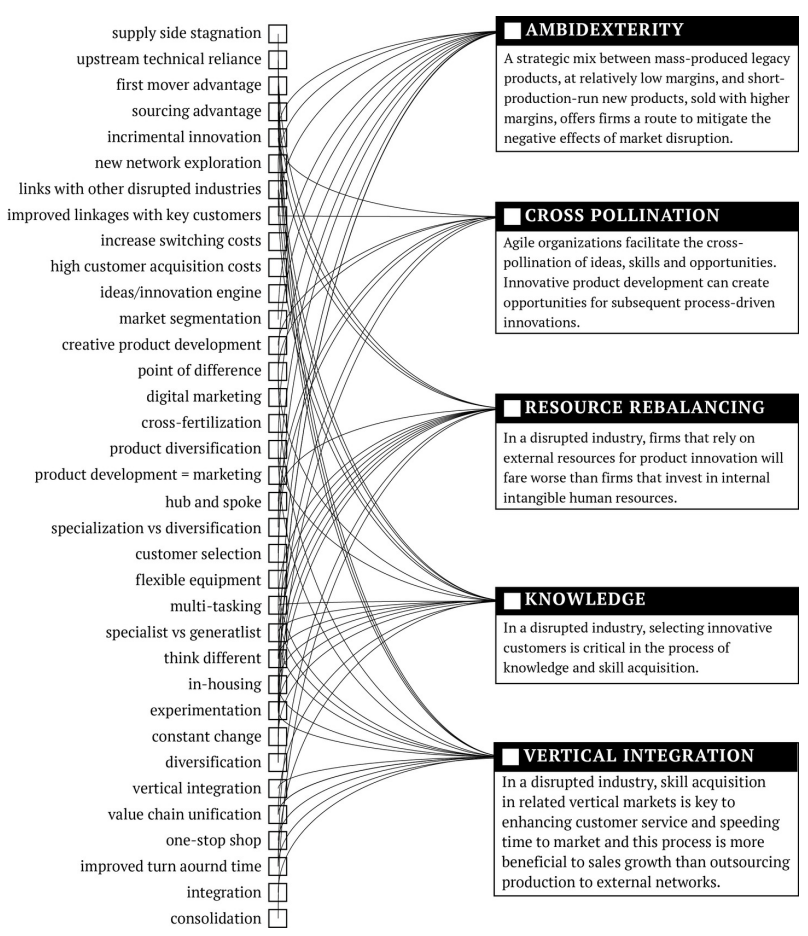

Figure 2. Development of research proposal from keyword analysis

\section{Ecosystem Reconfiguration}

Previously, a dynamic market was fed by innovative solutions from equipment suppliers, but this is no longer the case. This has forced a re-examination of existing relationships - both upstream and downstream - as well as the entire ecosystem around the organization. In this environment, successful firms recognize that a dynamic customer operating in growing markets can demand innovative solutions from its suppliers, and this in turn drives the firm forward. Resource acquisition takes on a broader meaning beyond merely machinery or other capital assets and begins to encompass the suppliers, partners and customers the firm chooses to work with.

\section{Resource Utilization and Knowledge Management}

Managing the skills and expertise within companies is critical to ensure firms develop a competitive advantage. The firms in our sample achieved this by a superior utilization of resources, both tangible and intangible. If Taylorism focused on operational efficiency, firms in our sample focused more on operational creativity as a way of securing that competitive advantage. Mechanistic methods of production are still key, but new machinery is altering the balance between operator and machine and offering creative operators a chance to develop innovative product solutions. Similarly, successful firms apply process innovations developed with one customer to others, if not all their customers. This is forcing a reassessment of the firm's knowhow and knowledge management systems. 
Table 1. Commonality in approach amongst successful firms in the sample

\begin{tabular}{|c|c|c|c|c|c|}
\hline \multirow{2}{*}{ Firm } & \multicolumn{3}{|c|}{ New Ecosystems } & \multirow{2}{*}{ Resource Optimization } & \multirow{2}{*}{ Exploration vs Exploitatior } \\
\hline & Upstream & Downstream & Horizontal & & \\
\hline A & & $\bullet$ & & $\bullet$ & $\bullet$ \\
\hline B & $\bullet$ & & $\bullet$ & $\bullet$ & $\bullet$ \\
\hline C & $\bullet$ & $\bullet$ & & & - \\
\hline $\mathrm{D}$ & $\bullet$ & & & $\bullet$ & \\
\hline $\mathrm{E}$ & & & $\bullet$ & $\bullet$ & $\bullet$ \\
\hline $\mathrm{F}$ & & & $\bullet$ & $\bullet$ & $\bullet$ \\
\hline G & $\bullet$ & $\bullet$ & $\bullet$ & $\bullet$ & $\bullet$ \\
\hline $\mathrm{H}$ & $\bullet$ & $\bullet$ & & $\bullet$ & \\
\hline I & & & & & $\bullet$ \\
\hline$J$ & $\bullet$ & $\bullet$ & $\bullet$ & $\bullet$ & \\
\hline K & & & & $\bullet$ & \\
\hline $\mathrm{L}$ & $\bullet$ & & $\bullet$ & & $\bullet$ \\
\hline M & & & $\bullet$ & & $\bullet$ \\
\hline N & & & & $\bullet$ & $\bullet$ \\
\hline
\end{tabular}

Note: Examples of exact strategies have not been included in this paper to preserve the anonymity of the firms who cooperated in this research.

\section{Rebalancing Exploration vs Exploitation}

In non-munificent DDI environments, firms can suffer from a surplus of obsolete resources. If demand is falling, then unit costs can increase. Focusing on what you know best when disrupted is a path often followed with poor results. Retaining your core competitive advantage is often prioritized as a way of overcoming external threats.

We have observed that when an industry is disrupted, incumbent firms first tend to shift the focus of their investment to maximizing the returns from the exploitation of existing (legacy) product opportunities (perceived as "safe") over investing in the exploration of innovative new product opportunities (perceived as "dangerous). But in a DDI, incremental innovation will not likely provide the necessary momentum for growth - entrepreneurs must seek more revolutionary changes.

We can summarize the successful strategies employed by firms in our sample in Table 1 and Figure 3. Almost all firms were actively working to reshape their ecosystems, whether through vertical integration or the building of new networks. This enabled a fuller set of skills to meet the requirements of a new, more dynamic customer base. Reassessing the source of competitive advantage, firms focused more on knowledge creation and knowledge management - offering employers more of a role in product development or ensuring that process innovation developed in one part of the business spreads to all parts of the business. Finally, successful entrepreneurs recognized the danger of an over-focus on legacy products and customers with declining demand. Incremental innovation is insufficient to survive a DDI - radical exploration of new markets and new technologies is critical.

\section{Conclusion, Limitations, and Implications}

This study sought to discover what actions taken by entrepreneurs in a DDI enhanced the innovative capabilities of the organization and contributed to the survival of their firm. In choosing sample firms from a single DDI, we aimed to remove not only the effects of munificence, but also the unexplained variance due to diverse industry-specific forces impacting on the firms. Using an interpretive process, our aim has been to develop concepts from the way in which entrepreneurs interpret their reality. We explored how successful firms have developed "new modes of interacting and organizing” (Suddaby, 2006). This study demonstrates the importance of a multiplicity of approaches linking marketing and product/process development and an evaluation of both internal structures and external linkages that entrepreneurs must build to cope with rapid change.

Of course this paper has limitations. Despite our efforts to select a controlled sample, we recognize that the market for print is diverse. Moreover, respondents were spread across a broad continent and were thus subject to a variety of local business environments. This inevitably raises questions as to the representativeness of our sample. Furthermore, is the Australian printing industry similar to other DDIs, such as travel agents or small retailers, and/or in other nations? Would a similar diversity of strategic responses also be found in other DDIs, or would causal strategy configurations in our chosen DDI be similarly diversity in other business and social environments?

Next, we must ask whether the implied measures of survival in this study (i.e. modest but sustained growth) are appropriate. Baum \& Wally (2003) suggest two main measures of performance, namely growth and profitability, but others have indicated that organizational effectiveness can be measured as a combination of financial indicators and 


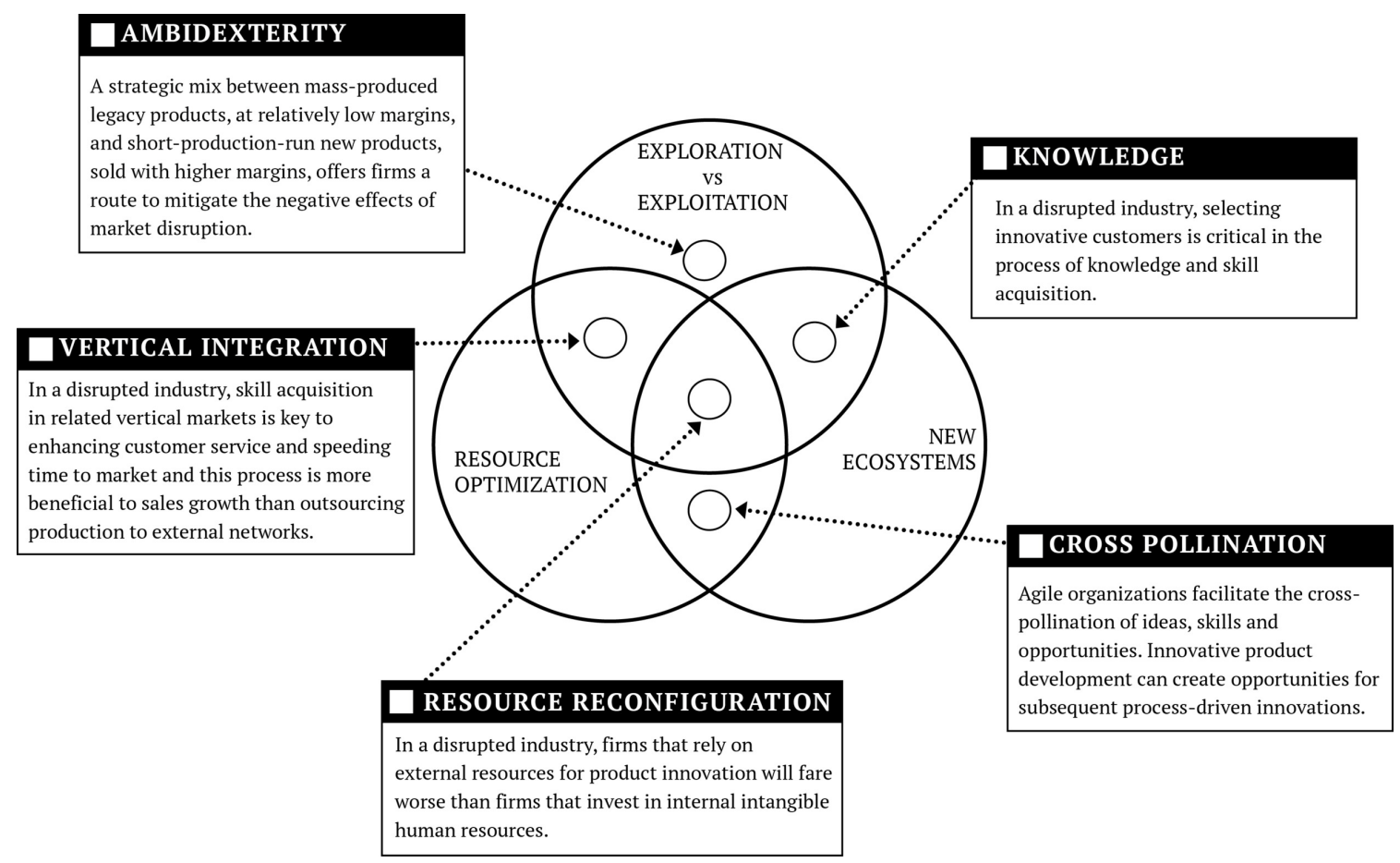

Figure 3. Relationship between propositions and strategy

operational performance. Profitability as a measure of success overlooks the fact that business owners may use profit in different ways depending on many factors (reinvestment and write offs are just two examples). Measuring performance based on survival and sales growth carries the implicit assumption that these variables are the prime objectives of the entrepreneur. Other possible rewards could include psychic income (Gimeno et al., 1997), socio-emotional wealth (Gomez-Mejia et al., 2011) or social development goals (Mair et al., 2006).

Thus there are several implications for future research on the entrepreneurial strategy of firms in a DDI. There is a need for quantitative research to test the propositions generated, which will require the development of relevant constructs and metrics to create testable, generalizable hypotheses from the propositions outlined in this paper. Data collection from the full spectrum of the print industry, and from other DDIs, cross-referenced with longevity and growth rates, would reveal whether or not the above propositions are supported in other DDIs. The firms in this study followed a variety of apparently equifinal pathways to continuing survival, so any subsequent analytical method must be able to identify configurations of strategies that each auger for continued survival and success. Traditional correlational methods, such as multiple regression and structural equation modeling, are not designed to reveal the equifinality of multiple pathways to the same outcome (Douglas et al., 2020). Instead, fuzzy-set qualitative comparative analysis (fsQCA) could be utilized to inductively identify combinations of strategies that culminate with equifinality in the survival of disrupted firms (Woodside, 2013). The fsQCA method is inductive, revealing configurations of antecedent conditions in the data that are not revealed by traditional methods. Within a larger sample it can identify several configurations, each representing a subgroup of firms, where each configuration culminates in firm survival. But while this inductive method reveals the configurations as combinations of antecedent conditions (strategies, in this case) that are consistently associated with the focal outcome (survival, in this case), it does not explain how or why those conditions interact to apparently cause the focal outcome - this is the task for subsequent theory building and empirical testing (Douglas et al., 2020). 


\section{REFERENCES}

Acs, Z. J., Stam, E., Audretsch, D. B., \& O’Connor, A. (2017). The lineages of the entrepreneurial ecosystem approach. Small Business Economics, 49(1), 1-10. http s://doi.org/10.1007/s11187-017-9864-8

Anderson, C. (2009). The longer long tail: How endless choice is creating unlimited demand. Random House.

Argote, L., \& Ingram, P. (2000). Knowledge transfer: A basis for competitive advantage in firms.

Organizational Behavior and Human Decision Processes, 82(1), 150-169. https://doi.org/10.1006/ob hd.2000.2893

Ashworth, C. J. (2012). Marketing and organisational development in e-SMEs: Understanding survival and sustainability in growth-oriented and comfort-zone pure-play enterprises in the fashion retail industry. International Entrepreneurship and Management Journal, 8(2), 165-201. https://doi.org/10.1007/s1136 5-011-0171-6

Augier, M., \& Teece, D. J. (2009). Dynamic capabilities and the role of managers in business strategy and economic performance. Organization Science, 20(2), 410-421. https://doi.org/10.1287/orsc.1090.0424

Australian Bureau of Statistics. (2016). 8165.0 Counts of Australian businesses, including entries and exits, Jun 2012 to Jun 2016.

Baker, T., \& Nelson, R. E. (2005). Creating something from nothing: Resource construction through entrepreneurial bricolage. Administrative Science Quarterly, 50(3), 329-366. https://doi.org/10.2189/asq u.2005.50.3.329

Barney, J. B. (1991). Firm resources and sustained competitive advantage. Journal of Management, 17(1), 99-120. https://doi.org/10.1177/01492063910170010 $\underline{8}$

Barney, J. B., Ketchen, D. J., \& Wright, M. (2011). The future of resource-based theory: revitalization or decline? Journal of Management, 37(5), 1299-1315. htt ps://doi.org/10.1177/014920639101700108

Baum, J. R., \& Wally, S. (2003). Strategic decision speed and firm performance. Strategic Management Journal, 24(11), 1107-1129. https://doi.org/10.1002/smj.343

Beliaeva, T., Shirokova, G., Wales, W., \& Gafforova, E. (2020). Benefiting from economic crisis? Strategic orientation effects, trade-offs, and configurations with resource availability on SME performance. International Entrepreneurship and Management Journal, 16(1), 165-194. https://doi.org/10.1007/s113 65-018-0499-2

Bodlaj, M., \& Čater, B. (2019). The impact of environmental turbulence on the perceived importance of innovation and innovativeness in SMEs. Journal of Small Business Management, 57(sup2), 417-435. https://doi.org/10.1111/jsbm.1248 2
Brinckmann, J., Villanueva, J., Grichnik, D., \& Singh, L. (2019). Sources of strategic flexibility in new ventures: An analysis of the role of resource leveraging practices. Strategic Entrepreneurship Journal, 13(2), 154-178. https://doi.org/10.1002/sej.1 $\underline{313}$

Brown, R., \& Mason, C. (2014). Inside the high-tech black box: A critique of technology entrepreneurship policy. Technovation, 34(12), 773-784. https://doi.org/ 10.1016/j.technovation.2014.07.013

Burnham, T. A., Frels, J. K., \& Mahajan, V. (2003). Consumer switching costs: A typology, antecedents, and consequences. Journal of the Acad of Marketing Science, 31(2), 109-126. https://doi.org/10.1177/0092 070302250897

Burns, T., \& Stalker, G. M. (1961). The Management of Innovation. Oxford Scholarship Online.

Capello, R., \& Lenzi, C. (2016). Innovation modes and entrepreneurial behavioral characteristics in regional growth. Small Business Economics, 47(4), 875-889. htt ps://doi.org/10.1007/s11187-016-9741-X

Castrogiovanni, G. J. (1991). Environmental Munificence; A Theoretical Assessment. Academy of Management Review, 16(3), 542-565. https://doi.org/1 $\underline{0.5465 / \mathrm{amr} .1991 .4279475}$

Christensen, C. M., \& Bower, J. L. (1995). Disruptive technologies: Catching the wave. Harvard Business Review, January, 43-54. https://doi.org/10.1016/004

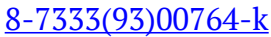

Clarysse, B., Bruneel, J., \& Wright, M. (2011). Explaining growth paths of young technology-based firms: Structuring resource portfolios in different competitive environments. Strategic Entrepreneurship Journal, 5(2), 137-157. https://doi.org/10.1002/sej.111

Cohen, W. M., \& Levinthal, D. A. (1990). Absorptive capacity: A new perspective on learning and innovation. Administrative Science Quarterly, 35(1), 128-152. https://doi.org/10.2307/2393553

Cooper, A. C. (1964). R \& D is more efficient in small companies. Harvard Business Review, 75-83.

Corrente, S., Greco, S., Nicotra, M., Romano, M., \& Schillaci, C. E. (2019). Evaluating and comparing entrepreneurial ecosystems using SMAA and SMAAS. Journal of Technology Transfer, 44(2), 485-519. http s://doi.org/10.1007/s10961-018-9684-2

Covin, J. G., \& Slevin, D. P. (1989). Strategic management of small firms in hostile and benign environments. Strategic Management Journal, 10(1), 75-87. https://doi.org/10.1002/smj.4250100107

Danneels, E. (2004). Disruptive technology reconsidered: A critique and research agenda. Journal of Product Innovation Management, 21(4), 246-258. ht tps://doi.org/10.1111/j.0737-6782.2004.00076.x

Davidsson, P., Recker, J., \& Von Briel, F. (2017). External enablers in new venture creation processes: A framework. Academy of Management Proceedings, 2017(1), 13126. https://doi.org/10.5465/ambpp.2017.1 $\underline{2}$ 
De Carolis, D. M., Yang, Y., Deeds, D. L., \& Nelling, E. (2009). Weathering the storm: The benefit of resources to high-technology ventures navigating adverse events. Strategic Entrepreneurship Journal, 3(2), 147-160. https://doi.org/10.1002/sej.68

de Vasconcelos Gomes, L. A., Facin, A. L. F., Salerno, M. S., \& Ikenami, R. K. (2018). Unpacking the innovation ecosystem construct: Evolution, gaps and trends. Technological Forecasting and Social Change, 136, 30-48. https://doi.org/10.1016/j.techfore.2016.11.009

Dewald, J., \& Bowen, F. (2010). Storm clouds and silver linings: Responding to disruptive innovations through cognitive resilience. Entrepreneurship Theory and Practice, 34(1), 197-218. https://doi.org/10.1111/ j.1540-6520.2009.00312.x

Douglas, E. J., Shepherd, D. A., \& Prentice, C. (2020). Using fuzzy-set qualitative comparative analysis for a finer-grained understanding of entrepreneurship. Journal of Business Venturing, 35(1), 105970. https://d oi.org/10.1016/i.jbusvent.2019.105970

Eisenhardt, K. M. (1989). Building theories from case study research. Academy of Management Review, 14(4), 532-550. https://doi.org/10.5465/amr.1989.4308385

Eisenhardt, K. M., \& Martin, J. A. (2000). Dynamic Capabilities: What Are They? Strategic Management Journal, 21(10), 1105-1121. https://onlinelibrary.wile y.com/doi/10.1002/1097-0266(200010/11)21:10/11\%3 C1105::AID-SMJ133\%3E3.0.CO;2-E

Feder, C. (2018). The effects of disruptive innovations on productivity. Technological Forecasting and Social Change, 126, 186-193. https://doi.org/10.1016/j.techf ore.2017.05.009

Flick, U. (2006). An introduction to qualitative research.

Freel, M. S. (2005). Patterns of innovation and skills in small firms. Technovation, 25(2), 123-134. https://do i.org/10.1016/s0048-7333(02)00084-7

Gans, J. S., \& Stern, S. (2003). The product market and the market for "ideas": Commercialization strategies for technology entrepreneurs. Research Policy, 32(2), 333-350. https://doi.org/10.1016/s0048-7333(02)001 $\underline{03-8}$

García-Gutiérrez, I., \& Martínez-Borreguero, F. J. (2016). The Innovation Pivot Framework: Fostering Business Model Innovation in Startups. ResearchTechnology Management, 59(5), 48-56. https://doi.or $\mathrm{g} / 10.1080 / 08956308.2016 .1208043$

George, G. (2005). Slack resources and the performance of privately held firms. Academy of Management Journal, 48(4), 661-676. https://doi.org/10.5465/amj.2 005.17843944

Gilbert, C., \& Bower, J. L. (2002). Disruptive change When trying harder is part of the problem. Harvard Business Review, 80(5), 94-101.

Gimeno, J., Folta, T. B., Cooper, A. C., \& Woo, C. Y. (1997). Survival of the Fittest? Entrepreneurial Human Capital and the Persistence of Underperforming Firms. Administrative Science Quarterly, 42(4), 750-783. https://doi.org/10.2307/23 $\underline{93656}$
Giones, F., \& Brem, A. (2017). Digital technology entrepreneurship: A definition and research agenda. Technology Innovation Management Review, 7(5), 44-51. https://doi.org/10.22215/timreview/1076

Gomezel, A. S., \& Rangus, K. (2018). An exploration of an entrepreneur's open innovation mindset in an emerging country. Management Decision, 56(9), 1869-1882. https://doi.org/10.1108/md-04-2017-038 $\underline{2}$

Gomez-Mejia, L. R., Cruz, C., Berrone, P., \& De Castro, J. (2011). The bind that ties: Socioemotional wealth preservation in family firms. Academy of Management Annals, 5(1), 653-707. https://doi.org/10.5465/194165 20.2011.593320

Grégoire, D. A., Barr, P. S., \& Shepherd, D. A. (2010). Cognitive Processes of Opportunity Recognition: The Role of Structural Alignment. Organization Science, 21(2), 413-431. https://doi.org/10.1287/orsc.1090.046 $\underline{2}$

Gupta, V. K., Niranjan, S., Goktan, B. A., \& Eriskon, J. (2016). Individual entrepreneurial orientation role in shaping reactions to new technologies. International Entrepreneurship and Management Journal, 12(4), 935-961. https://doi.org/10.1007/s11365-015-0373-4

Hambrick, D. C., \& Mason, P. A. (1984). Upper echelons: The organization as a reflection of its top managers. Academy of Management Review, 9(2), 193-206. http s://doi.org/10.5465/amr.1984.4277628

Hill, C. W. L., \& Rothaermel, F. T. (2003). The performance of incumbent firms in the face of radical technological innovation. Academy of Management Review, 28(2), 257-274. https://doi.org/10.5465/amr.2 $\underline{003.9416161}$

Hornsby, J. S., Covin, J. G., \& Kuratko, D. F. (2014). Why implementing corporate innovation is so difficult. Business Horizons, 57(5), 647-655. https://doi.org/1 0.1016/j.bushor.2014.05.007

Huggins, R., \& Thompson, P. (2015). Entrepreneurship, innovation and regional growth: A network theory. Small Business Economics, 45(1), 103-128. https://do i.org/10.1007/s11187-015-9643-3

Jeng, D. J., \& Hung, T. H. (2019). Comeback of the failed entrepreneur: An integrated view of costs, learning, and residual resources associated with entrepreneurial failure. Journal of Small Business Strategy, 29(1), 30-42.

Jifri, A. O., Drnevich, P., \& Tribble, L. (2016). The role of absorbed slack and potential slack in improving small business performance during economic uncertainty. Journal of Strategy and Management, 9(4), 474-491. ht tps://doi.org/10.1108/jsma-03-2015-0024

Keating, A., Geiger, S., \& McLoughlin, D. (2014). Riding the practice waves: Social resourcing practices during new venture development. Entrepreneurship Theory and Practice, 38(5), 1-29. https://doi.org/10.1111/eta p. 12038

Kerr, W., Glaeser, E., \& Chatterji, A. (2014). Clusters of entrepreneurship and innovation. National Bureau of Economic Research, 14(1), 129-166. https://doi.org/1 $\underline{0.1086 / 674023}$ 
Kickul, J., \& Gundry, L. (2002). Prospecting for strategic advantage: The proactive entrepreneurial personality and small firm innovation. Journal of Small Business Management, 40(2), 85-97. https://doi.org/10.1111/15 40-627x.00042

Kirtley, J., \& O’Mahony, S. (2018). What is a Pivot? Explaining When and How Entrepreneurial Firms Decide to Make Strategic Change and Pivot. Strategic Management Journal, 49(4), 473-495. https://doi.org/1 0.1002/smj.3131

Klemperer, P. (1987). Markets with consumer switching costs. The Quarterly Journal of Economics, 102(2), 375-394. https://doi.org/10.2307/1885068

Koberg, C. S., Detienne, D. R., \& Heppard, K. A. (2003). An empirical test of environmental, organizational, and process factors affecting incremental and radical innovation. The Journal of High Technology Management Research, 14(1), 21-45. https://doi.org/1 $\underline{0.1016 / \mathrm{s} 1047-8310(03) 00003-8}$

Kyläheiko, K., Jantunen, A., Puumalainen, K., \& Luukka, P. (2011). Value of knowledge-Technology strategies in different knowledge regimes. International Journal of Production Economics, 131(1), 273-287. https://do i.org/10.1016/j.ijpe.2010.07.009

Lévi-Strauss, C. (1966). The Savage Mind. University of Chicago Press.

Liu, H., \& Yang, H. (2019). Managing Network Resource and Organizational Capabilities to Create Competitive Advantage for SMEs in a Volatile Environment. Journal of Small Business Management, 57(sup2), 155-171. https://doi.org/10.1111/jsbm.1244 $\underline{9}$

Llanos-Contreras, O., Alonso-Dos-Santos, M., \& Ribeiro-Soriano, D. (2020). Entrepreneurship and risk-taking in a post-disaster scenario. International Entrepreneurship and Management Journal, 16(1), 221-237. https://doi.org/10.1007/s11365-019-0059 $\underline{0-9}$

Lubatkin, M. H., Simsek, Z., Ling, Y., \& Veiga, J. F. (2006). Ambidexterity and performance in small-to medium-sized firms: The pivotal role of top management team behavioral integration. Journal of Management, 32(5), 646-672. https://doi.org/10.1177/ $\underline{0149206306290712}$

Mair, J., Robinson, J., \& Hockerts, K. (Eds.). (2006). Social Entrepreneurship. Palgrave Macmillan.

Miller, D., \& Friesen, P. H. (1982). Innovation in conservative and entrepreneurial firms: Two models of strategic momentum. Strategic Management Journal, 3(1), 1-25. https://doi.org/10.1002/smj.42500 $\underline{30102}$

Miller, D., \& Toulouse, J.-M. (1986). Chief executive personality and corporate strategy and structure in small firms. Management Science, 32(11), 1389-1409. https://doi.org/10.1287/mnsc.32.11.1389

Morris, M. H., Neumeyer, X., \& Kuratko, D. F. (2015). A portfolio perspective on entrepreneurship and economic development. Small Business Economics, 45(4), 713-728. https://doi.org/10.1007/s11187-015-9 $\underline{678-5}$
Neill, S., \& York, J. L. (2012). The entrepreneurial perceptions of strategy makers: Constructing an exploratory path in the pursuit of radical growth. Journal of Business Research, 65(7), 1003-1009. http s://doi.org/10.1016/j.jbusres.2011.04.009

Nohria, N., \& Gulati, R. (1996). Is slack good or bad for innovation? Academy of Management Journal, 39(5), 1245-1264. https://doi.org/10.5465/256998

O’Regan, N., \& Ghobadian, A. (2005). Innovation in SMEs: The impact of strategic orientation and environmental perceptions. International Journal of Productivity and Performance Management, 54(2), 81-97. https://doi.org/10.1108/17410400510576595

Osiyevskyy, O., \& Dewald, J. (2015). Inducements, impediments, and immediacy: Exploring the cognitive drivers of small business managers' intentions to adopt business model change. Journal of Small Business Management, 53(4), 1011-1032. http s://doi.org/10.1111/jsbm.12113

Penrose, E. T. (1960). The growth of the firm - A case study: The Hercules Powder Company. Business History Review, 34(1), 1-23. https://doi.org/10.2307/3 111776

Pirolo, L., \& Presutti, M. (2010). The Impact of Social Capital on the Start-ups' Performance Growth. Journal of Small Business Management, 48(2), 197-227. https://doi.org/10.1111/j.1540-627x.2010.00292.x

Powell, E. E., \& Baker, T. (2011). Beyond making do: Toward a theory of entrepreneurial resourcefulness. Frontiers of Entrepreneurship Research, 31(12), 376-388.

Ritala, P., Olander, H., Michailova, S., \& Husted, K. (2015). Knowledge sharing, knowledge leaking and relative innovation performance: An empirical study. Technovation, 35, 22-31. https://doi.org/10.1016/i.tec hnovation.2014.07.011

Rosenbusch, N., Brinckmann, J., \& Bausch, A. (2011). Is innovation always beneficial? A meta-analysis of the relationship between innovation and performance in SMEs. Journal of Business Venturing, 26(4), 441-457. $\underline{\mathrm{h}}$ ttps://doi.org/10.1016/j.jbusvent.2009.12.002

Roy, R., Lampert, C. M., \& Stoyneva, I. (2018). When dinosaurs fly: The role of firm capabilities in the 'avianization' of incumbents during disruptive technological change. Strategic Entrepreneurship Journal, 12(2), 261-284. https://doi.org/10.1002/sej.1 $\underline{278}$

Sahut, J., \& Peris-Ortiz, M. (2014). Small business, innovation, and entrepreneurship. Small Business Economics, 42(4), 663-666. https://doi.org/10.1016/i.j busvent.2009.12.002

Salder, J., Gilman, M., Raby, S., \& Gkikas, A. (2020). Beyond linearity and resource-based perspectives of SME growth. Journal of Small Business Strategy, 30(1), $1-17$.

Sarasvathy, S. D. (2001). Causation and effectuation: Towards a theoretical shift from economic inevitability to entrepreneurial contingency. Academy of Management Review, 26(2), 243-263. https://doi.or $\mathrm{g} / 10.5465 / \mathrm{amr} .2001 .4378020$

Schumpeter, J. A. (1934). The theory of economic development. Harvard Business School Press. 
Seawright, J., \& Gerring, J. (2008). Case selection techniques in case study research. Political Research Quarterly, 61(2), 294-308. https://doi.org/10.1177/10 $\underline{65912907313077}$

Secundo, G., Schiuma, G., \& Passiante, G. (2017). Entrepreneurial learning dynamics in knowledgeintensive enterprises. International Journal of Entrepreneurial Behavior \& Research, 23(3), 366-380. https://doi.org/10.1108/ijebr-01-2017-0020

Senyard, J. M., Baker, T., \& Davidsson, P. (2011). Bricolage as a path to innovation for resource constrained new firms. Academy of Management Proceedings, 2011(1), 1-5. https://doi.org/10.5465/am bpp.2011.65869700

Sequeira, J., Weeks, K. P., Bell, M. P., \& Gibbs, S. R. (2018). Making the case for diversity as a strategic business tool in small firm survival and success. Journal of Small Business Strategy, 28(3), 31-47.

Shepherd, D. A. (2003). Learning from business failure: Propositions of grief recovery for the self-employed. Academy of Management Review, 28(2), 318-328. http s://doi.org/10.5465/amr.2003.9416377

Sheppard, M. (2018). The relationship between discretionary slack and growth in small firms. International Entrepreneurship and Management Journal, 16(1), 1-25. https://doi.org/10.1007/s11365-0 18-0498-3

Spithoven, A., Vanhaverbeke, W., \& Roijakkers, N. (2013). Open innovation practices in SMEs and large enterprises. Small Business Economics, 41(3), 537-562. https://doi.org/10.1007/s11187-012-9453-9

Suddaby, R. (2006). From the Editors: What Grounded Theory is Not. Academy of Management Journal, 49(4), 633-642. https://doi.org/10.5465/amj.2006.22083020

Tehseen, S., Ahmed, F. U., Qureshi, Z. H., Uddin, M. J., \& Thurasamy, R. (2019). Entrepreneurial competencies and SMEs' growth: The mediating role of network competence. Asia-Pacific Journal of Business Administration, 11(1), 2-29. https://doi.org/1 0.1108/apjba-05-2018-0084

Tripsas, M. (1997). Surviving radical technological change through dynamic capability: Evidence from the Typesetter Industry. Industrial and Corporate Change, 6(2), 341-377. https://doi.org/10.1093/icc/ 6.2.341

Tushman, M. L., \& Nelson, R. R. (1990). Introduction: Technology, organizations, and innovation. Administrative Science Quarterly, 35(1), 1-8. https://do i.org/10.2307/2393548

Ucbasaran, D., Shepherd, D. A., Lockett, A., \& Lyon, S. J. (2013). Life after business failure: The process and consequences of business failure for entrepreneurs. Journal of Management, 39(1), 163-202. https://doi.or $\mathrm{g} / 10.1177 / 0149206312457823$
Vecchiato, R. (2017). Disruptive innovation, managerial cognition, and technology competition outcomes. Technological Forecasting and Social Change, 116, 116-128. https://doi.org/10.1016/j.techfore.2016.10.0 $\underline{68}$

Wang, L., Li, E. P. H., \& Ding, X. S. (2018). Does deliberate learning lead to dynamic capability? The role of organizational schema for Kodak, 1993-2011. Journal of Strategy and Management, 11(1), 52-80. htt ps://doi.org/10.1108/jsma-11-2016-0083

Welter, F., Xheneti, M., \& Smallbone, D. (2018). Entrepreneurial resourcefulness in unstable institutional contexts: The example of European Union borderlands. Strategic Entrepreneurship Journal, 12(1), 23-53. https://doi.org/10.1002/sej.1274

Winborg, J., \& Landström, H. (2001). Financial Bootstrapping in Small Businesses: Examining Small Business Managers' Resource Acquisition Behaviors. Journal of Business Venturing, 16(3), 235-254. http s://doi.org/10.1016/s0883-9026(99)00055-5

Wood, M. S., Palich, L. E., \& Browder, R. E. (2019). Full steam ahead or abandon ship? An empirical investigation of complete pivot decisions. Journal of Small Business Management, 57(4), 1637-1660. http s://doi.org/10.1111/jsbm.12437

Woodside, A. G. (2013). Moving beyond multiple regression analysis to algorithms: Calling for adoption of a paradigm shift from symmetric to asymmetric thinking in data analysis and crafting theory. Journal of Business Research, 66(4), 463-472. $\mathrm{h}$ ttps://doi.org/10.1016/j.jbusres.2012.12.021

Xi, Y., Yu, J., Wang, Y., \& Zhou, J. X. (2013). Rural entrepreneurship in an emerging economy: Reading institutional perspectives from entrepreneur stories. Journal of Small Business Management, 51(2), 183-195. https://doi.org/10.1111/jsbm.12012

Yazici, S., Köseoglu, M. A., \& Okumus, F. (2016). Identification of growth factors for small firms: Evidence from hotel companies on an island. Journal of Organizational Change Management, 29(6), 994-1029. https://doi.org/10.1108/jocm-12-2015-023 1

Yin, R. K. (2003). Case study research: Design and methods. Sage Publications.

York, J. L., \& Danes, J. E. (2014). Customer development, innovation, and decision-making biases in the lean start-up. Journal of Small Business Strategy, 24(2), 21-40.

Yu, D., \& Hang, C. C. (2010). A reflective review of disruptive innovation theory. International Journal of Management Reviews, 12(4), 435-452. https://doi.org/ 10.1111/j.1468-2370.2009.00272.x

Zahra, S. A., Filatotchev, I., \& Wright, M. (2009). How do threshold firms sustain corporate entrepreneurship? The role of boards and absorptive capacity. Journal of Business Venturing, 24(3), 248-260. https://doi.org/1 $\underline{0.1016 / j . j b u s v e n t .2008 .09 .001}$ 